Dariusz Brzegowy, Dyspensa od małżeństwa zawartego i niedopetnionego - aspekt doktrynalny i procesowy wraz w praktyką Sądu Diecezjalnego w Tarnowie, [w:] Struktura i działalność Sądu Diecezjalnego w Tarnowie w latach 1983-2015, red. Robert Kantor, Kraków 2016, s. 103-120.

DOI: http://dx.doi.org/10.15633/9788374385299.07

KS. DARIUSZ BRZEgOWY

Sąd Diecezjalny w Tarnowie

\title{
Dyspensa od małżeństwa zawartego i niedopełnionego - aspekt doktrynalny i procesowy wraz w praktyką Sądu Diecezjalnego w Tarnowie
}

Przedmiotem niniejszego opracowania jest instytucja małżeństwa ochrzczonych ujęta w perspektywie jego dopełnienia w świetle aktualnego ustawodawstwa Kościoła, a także kanoniczny przebieg postepowania $\mathrm{w}$ sprawie o uzyskanie dyspensy super rato i jego recepcja w praktyce tarnowskiego sądu diecezjalnego w latach 1983-2015. Studium składa się z trzech części, z których dwie pierwsze pełnią funkcję ogólnej prezentacji materialnych i procesowych zagadnień dotyczących kwestii związanych z niedopełnieniem małżeństwa, trzecia zaś część jest próbą syntetycznego scharakteryzowania postepowań dotyczących uzyskania dyspensy super rato, mających miejsce $\mathrm{w}$ diecezjalnym sądzie tarnowskim w okresie obowiązywalności aktualnego Kodeksu prawa kanonicznego.

\section{Dopełnienie małżeństwa pomiędzy ochrzczonymi i jego kanoniczne konsekwencje}

Związek małżeński, rozumiany jako przymierze mężczyzny i kobiety, został pomiędzy ochrzczonymi podniesiony przez Chrystusa do godności sakramentu, stąd też nie może istnieć między nimi żadna inna umowa małżeńska, która tym samym nie byłaby sakramentem ${ }^{1}$.

\footnotetext{
Por. KPK kan. $1055 \$ \$ 1-2$.
} 
Związek ten, jak podaje kan. $1061 \$ 1$ Kodeksu prawa kanonicznego Z 1983 [dalej: KPK] nazywa się tylko zawartym (ratum tantum), jeśli nie został dopełniony (consummatum); zawartym i dopełnionym (ratum et consummatum) jeśli małżonkowie podjęli w sposób ludzki akt małżeński.

W kontekście powyższego unormowania należy przed wszystkim zaznaczyć, bazując na stwierdzeniach doktryny, że „pierwszy akt małżeński można nazwać dopełnieniem w znaczeniu ścisłym teologicznym i kanonicznym, jeśli dokonuje się w małżeństwie pomiędzy ochrzczonymi. Nie ma on bowiem wpływu na istotę węzła małżeńskiego, ale wyłącznie na jego sakramentalny wymiar, dopełniając ten wymiar w taki sposób, iż małżeństwo oznacza absolutnie nierozerwalną jedność Chrystusa i Kościoła w jednym ciele"2.

Następnie należy zadać pytanie o biologiczne elementy aktu dopełniającego związek małżeński. Akt małżeński rozumiany jako cielesne zjednoczenie mężczyzny i kobiety, dokonany w sposób naturalny i pełny tworzą trzy istotne elementy, jakimi są: erekcja członka mężczyzny, penetracja waginy kobiety wraz z ejakulacją i złożeniem tam płynu nasiennego. Brak któregokolwiek z tych naturalnych elementów, niezależnie od przyczyn takiego stanu rzeczy, powoduje niekompletność aktu małżeńskiego lub jego intencjonalne całkowite wypaczenie, co w konsekwencji powoduje niedopełnienie małżeństwa ${ }^{3}$.

Seksualnego współżycia małżonków nie można jednak ograniczyć jedynie do przedstawionego wyżej wymiaru fizyczno-biologicznego, gdyż jako akt w pełni ludzki angażuje on także inne sfery człowieka, dotykając

\footnotetext{
A. Wójcik, Konsekwencje prawne dopetnienia i niedopetnienia małżeństwa w prawie kanonicznym, „Analecta Cracoviensia” 44 (2012), s. 311.

3 Pomocnymi we właściwym rozumieniu natury omawianego aktu i jego znaczenia w kontekście dopełnienia małżeństwa są wyjaśnienia, jakich w ubiegłym stuleciu udzieliła Kongregacja Świętego Oficjum, np. co do braku konieczności penetracji całkowitej (Odpowiedź De copula perfecta et de consummatione matrimonii z 1 marca 1941, [w:] X. Ochoa, Leges Ecclesiae post codicem iuris canonici editae, Romae 1966, vol. 1, n. 1599, kol. 2050), czy też braku znaczenia praktyki stosowania środków wzmacniających sprawność seksualną (Odpowiedź De consummatione matrimonii z 1 lutego 1949, [w:] X. Ochoa, Leges Ecclesiae..., dz. cyt., Romae 1969, vol. 2, n. 2024, kol. 2565). Warto wskazać też odpowiedź wydaną w odniesieniu do określenia przeszkody impotencji, stwierdzającą brak ejakulacji płynu powstałego w jądrach jako niemający charakteru uniezdalniającego do zawarcia małżeństwa (Kongregacja Doktryny Wiary, Dekret Utrum impotentia z 13 maja 1977, „Acta Apostolicae Sedis" [dalej: AAs] 69 (1977) s. 426).
} 
głębi jego władz poznawczo-wolitywnych i powodując pełne i wyłączne zjednoczenie osób ${ }^{4}$. Stąd kodeksowe unormowanie wskazujące na wymiar prawdziwie ludzki aktu (kan. $1061 \S 1$ ) oraz doprecyzowania, biorące pod uwagę wolność osoby w jego realizacji 5 .

Z faktu dopełnienia związku małżeńskiego wynikają określone i doniosłe skutki: kan. $1041 \mathrm{KPK}$ stwierdza bowiem, że małżeństwo zawarte i dopełnione nie może być rozwiązane żadną ludzką władzą i z żadnej przyczyny, oprócz śmierci. W konsekwencji norma ta nie może być pojmowana jako zasada czysto formalna o charakterze wyłącznie dyscyplinarnym, ale stanowi ona przesłanie doktrynalne, wielokrotnie potwierdzane przez Urząd Nauczycielski Kościoła, zarówno przed, jak i po sformułowaniu unormowania kodeksowego ${ }^{6}$.

Gdyby zaś z jakiejkolwiek przyczyny po zawarciu związku nie doszło do jego dopełnienia, małżeństwo to, zgodnie z dyspozycją kan. 1142, może być wskutek słusznej przyczyny rozwiązane powagą władzy biskupa Rzymu?.

4 „W ten sposób mężczyzna i kobieta, który przez związek małżeński «już nie są dwoje, lecz jedno ciało» (Mt 19, 6), przez najściślejsze zespolenie osób i działań świadczą sobie wzajemnie pomoc i posługę oraz doświadczają sensu swej jedności i osiągają ją w coraz pełniejszej mierze. To głębokie zjednoczenie będące wzajemnym oddaniem się sobie dwóch osób, jak również dobro dzieci, wymaga pełnej wierności małżonków i dąży ku nieprzerwalnej jedności ich współżycia”. Sobór Watykański II, konst. Gaudium et spes, 48.

5 „[...] ad habendam consummationem matrimonii oportet ut actus sit humanus ex utraque parte, sed sufficit ut sit virtualiter voluntarius, dummodo non violenter exigitus. Cetera elementa psychologica, quae actum humanum faciliorem vel magis appetibilem reddunt, non attenduntur”. Święta Kongregacja Sakramentów, List okólny De processu super matrimonio rato et non consummato [dalej: Ps] z 20 grudnia 1986, Wstęp, „Communicationes" 20 (1988), s. 78, 1.

6 Por. Pius XI, Enc. Casti connubii, Denzinger-Schönmetzer n. 3712; KKK n. 1640; Jan Paweł II, Przemówienie do audytorów Trybunału Roty Rzymskiej (21.1.2000), AAS 92 (2000), s. 354 .

7 „Małżeństwo niedopełnione, zawarte przez ochrzczonych lub między stroną ochrzczoną i stroną nieochrzczoną, może być ze słusznej przyczyny rozwiązane przez Biskupa Rzymskiego, na prośbę obydwu stron lub tylko jednej, choćby druga się nie zgadzała", KPK kan. 1142. 


\section{Przebieg postępowania o udzielenie dyspensy super rato w świetle aktualnego ustawodawstwa Kościoła}

Po syntetycznym zaprezentowaniu natury i elementów dopełnienia małżeństwa sakramentalnego oraz jego kanonicznych skutków zostaną przedstawione $\mathrm{w}$ niniejszym paragrafie istotne elementy procedury mającej na celu uzyskanie dyspensy od małżeństwa zawartego, lecz niedopełnionego. W celu umiejscowienia tego zagadnienia we właściwym kontekście należy wstępnie uczynić kilka uwag ogólnych dotyczących natury tego postępowania w odniesieniu do kanoniczego procesu o stwierdzenie nieważności małżeństwa.

Mimo iż obydwa rodzaje postępowania czynią zainteresowane osoby wolnymi w decyzji co do kolejnej celebracji małżeństwa, różnią się znacząco od siebie, zarówno materialnie, jak i w wymiarze praktycznym.

O ile wyrok w procesie o stwierdzenie nieważności koresponduje ściśle z wymogiem sprawiedliwości należnej w Kościele każdemu wiernemu, o tyle papieska dyspensa jest wyłącznie aktem łaski okazanej ze słusznej przyczyny konkretnym małżonkom dla ich dobra duchowego. Jak właściwie zauważa Józef Krukowski, nie można jednak mówić o dyspensie w znaczeniu, jakie wyraża w odniesieniu do tej instytucji dyspozycja kan. $85 \mathrm{KPK}^{8}$, chociażby z tego względu, że w omawianym przypadku nie jest ona rozluźnieniem prawa czysto kościelnego, lecz normy wynikającej z prawa Bożego i opartej na dogmatycznej prawdzie o nierozerwalności małżeństwa9.

Biorąc zatem pod uwagę administracyjny charakter postępowania $\mathrm{w}$ sprawie dyspensy super rato, należy stosować adekwatną do niego terminologię - i tak osoba ubiegająca się o dyspensę to nie strona powodowa, a petent (orator), sędziego prowadzącego sprawę należy określić mianem instruktora, gdyż nie wydaje on żadnego wyroku, lecz jedynie przeprowadza postępowanie dowodowe i wydaje o nim swoją opinię.

8 „Dispensatio, seu legis mere ecclesiasticae in casu particulari relaxatio, concedi potest $\mathrm{ab}$ iis qui potestate gaudent exsecutiva intra limites suae competentiae, necnon ab illis quibus potestas dispensandi explicite vel implicite competit sive ipso iure sive vi legitimae delegationis". К кК kan. 85.

9 Por. J. Krukowski, Proces o uzyskanie dyspensy od małżeństwa zawartego i niedopetnionego. Wstęp, [w:] Komentarz do Kodeksu Prawa Kanonicznego. T. 5. Ks. 7, Procesy, red. J. Krukowski, Poznań 2007, s. 378. 
Ponadto wykonalny pozytywny wyrok w sprawie o stwierdzenie nieważności małżeństwa osiąga swoją skuteczność ex tunc, sięgając do momentu celebracji, dyspensa zaś skutkuje z chwilą jej udzielenia (ex nunc).

Należy także podkreślić, że uzyskanie dyspensy nie zakłada uprzedniego wniesienia skargi o stwierdzenie nieważności małżeństwa, stąd też istnieje możliwość zapoczątkowania takiego procesu nawet po uzyskaniu reskryptu $\mathrm{z}$ dyspensą super rato, $\mathrm{w}$ takim wypadku do jego prowadzenia nie jest wymagana jakakolwiek forma papieskiej autoryzacji $1^{10}$.

Aktualne ustawodawstwo kodeksowe dotyczące natury i przebiegu procedury rozwiązania małżeństwa ważnego i niedopełnionego nie jest rozległe, zawiera się ono bowiem w 10 kanonach KPK (1697-1706) i jednej dyspozycji KKKW (kan. 1384), będących w dużej mierze odzwierciedleniem przepisów wydawanych w tej materii przez Kongregację Kultu Bożego i Dyscypliny Sakramentów w okresie obowiązywania kodyfikacji pio-benedyktyńskiej ${ }^{11}$. Praktycznym rozwinięciem tych dyspozycji jest List okólny z 20 grudnia 1986 roku wydany przez wspomnianą kongregację, a także dwie dyspozycje (art. 153 i 154) instrukcji Dignitas connubii [dalej: DC]. Innym dokumentem, jaki należy uwzględnić w analizowanej sprawie, jest list apostolski motu proprio Quaerit semper, wydany przez papieża Benedykta XVI 30 sierpnia 2011 roku, w którym przeniósł on - na drodze wyłączności - niektóre kompetencje Kongregacji Kultu Bożego i Dyscypliny Sakramentów do Trybunału Roty Rzymskiej ${ }^{12}$. Uprawnienia te dotyczą postępowania w sprawach o uzyskanie dyspensy od małżeństwa zawartego i niedopełnionego oraz w sprawach o stwierdzenie nieważności święceń ${ }^{13}$. Warto dodać, że przeniesienie kompetencji

${ }^{10}$ Por. Sekretariat Stanu, Komunikat Sygnatury Apostolskiej z 1 czerwca 1983, [w:] X. Ochoa, Leges Ecclesiae..., dz. cyt., n. 4980, kol. 8646.

${ }^{11}$ W tym kontekście przede wszystkim należy wskazać na dekret Catholica doctrina z 7 maja 1923 roku wraz z załączonymi do niego wytycznymi regulującymi przebieg procesu administracyjnego super rato, zatytułowanymi Regulae servandae (A AS 15 (1923) s. 389436). Warto dodać, że całość odnośnego ustawodawstwa, począwszy od rozporządzeń kodeksu z 1917 roku, została opublikowana przez wspomnianą kongregację w Collectanea documentorum ad causas por dispensatione super "rato et non consummato" et a lege sacri coelibatus obtinenda inde a Codice Iuris Canonici anni 1917, Città del Vaticano 2004.

${ }^{12}$ O historycznym ujęciu genezy tej decyzji zob. w: A. Stankiewicz, Un'innovazione storica, „Communicationes” 43 (2011) nr 2, s. 369.

${ }_{13}$ Zgodnie z dyspozycją art. $2 \$ \$ 2-3$ i 3 listu apostolskiego Quaerit semper został utworzony nowy urząd (Officium de processibus dispensationis super matrimonio rato et non 
dotyczących postępowania w sprawach udzielenia dyspensy super rato nie zmieniło niczego, gdy chodzi o przebieg poszczególnych czynności tworzących procedurę na etapie rotalnego rozpatrzenia sprawy.

W niniejszym opracowaniu pozostaniemy w tak zakreślonym obszarze prawnym, koncentrując się na przedstawieniu zasadniczych aspektów poszczególnych etapów postępowania.

Biorąc pod uwagę pierwszy z grupy wskazanych kanonów, należy zauważyć, iż podmiotem mającym legitymację prawną do wniesienia prośby o dyspensę są wyłącznie sami małżonkowie lub jedno z nich, nawet gdyby druga strona się nie zgadzała ${ }^{14}$. Takie sformułowanie wyklucza zatem jakiekolwiek inne osoby, przez co pozostaje w pewnej zbieżności z dyspozycją kan. 1674, z tą jednak różnicą, że w przeciwieństwie do procesu o stwierdzenie nieważności małżeństwa takiego prawa w odniesieniu do procedury super rato nie ma promotor sprawiedliwości.

Kolejna dyspozycja kodeksowa zawiera bardzo istotne rozróżnienie ${ }^{15}$. O ile bowiem rozpoznanie faktu niedopełnienia małżeństwa i wydanie oceny dotyczącej stosowności udzielenia aktu łaski przynależy wyłącznie Stolicy Apostolskiej, o tyle podmiotem decydującym o udzieleniu dyspensy jest wyłącznie osoba biskupa Rzymu, który z racji doniosłości tego aktu (uczynienie wyjątku od zasady nierozerwalności małżeństwa) ${ }^{16}$ nie upoważnia do tego innych ${ }^{17}$.

consummato ac causis nullitatis sacrae Ordinationis), włączony do struktury Roty Rzymskiej, którego kompetencje dotyczą dwóch rodzajów procesów: o uzyskanie dyspensy od małżeństwa zawartego i niedopełnionego (art. $2 \$ 2$ ) oraz o stwierdzenie nieważności święceń (art. $2 \$ 3$ ). Należy zauważyć, że choć w odniesieniu do spraw o dyspensę super rato pozostają w mocy przepisy zawarte W KPK kan. 1697-1706, występujący w nich zwrot „Stolica Apostolska” należy obecnie utożsamiać z Rotą Rzymską, nie zaś, jak dotąd, z Kongregacją Kultu Bożego i Dyscypliny Sakramentów, podobnie występujące w obowiązujących przepisach specjalnych listu okólnego ówczesnej Kongregacji Sakramentów z 20 grudnia 1986 roku odniesienia do „Kongregacji” również należy obecnie rozumieć jako skierowane do nowego Urzędu w Rocie Rzymskiej.

${ }_{14}$ Por. KPK kan. 1697.

${ }^{15}$ Por. KPK kan. 1698.

${ }^{16}$ Por. J. Krukowski, Kanon 1698, [w:] Komentarz do Kodeksu Prawa Kanonicznego. T. 5. Ks. 7, Procesy, dz. cyt., s. 38o. Jak słusznie zauważa autor, całość postępowania zmierza do wypracowania odpowiedzi na pytanie: czy należy udzielić rady Biskupowi Rzymskiemu, aby udzielił dyspensy? (An consulendum sit ss.mo pro dispensatione?). Por. J. Krukowski, Kanon 1698, dz. cyt., s. 380.

${ }_{17}$ Por. „Communicationes” 11 (1979), s. 275. 
Zgodnie z następną kodeksową dyspozycją (kan. 1699) regulującą materię dyspensy od małżeństwa niedopełnionego podmiotem właściwym do przyjęcia petycji oratora jest biskup diecezjalny miejsca jego stałego lub tymczasowego zamieszkania, a także wszyscy zrównani z nim w prawie, według dyspozycji kan. $134 \$ 3$; 368 i $381 \$ 2$. Co oczywiste, przed przyjęciem prośby winien on zbadać zasadność jej wniesienia, a gdyby zdaniem biskupa była ona pozbawiona podstaw, czy to prawnych, czy też faktycznych, nie powinien jej dopuszczać do instrukcji ${ }^{18}$. W tej sytuacji petentowi zgodnie $\mathrm{z}$ dyspozycją kan. $1699 \$ 3$ przysługuje prawo wniesienia rekursu do Roty Rzymskiej, która po zbadaniu motywów odwołania wydaje dekret przyjęcia lub oddalenia prośby.

W kontekście oceny zasadności wnoszonej prośby o rozpoczęcie postępowania super rato na szczególną uwagę zasługuje norma kan. 1699 $\$ 2$, w której zaleca się biskupowi zasięgnięcie rady Stolicy Apostolskiej w odniesieniu do tzw. przypadków trudniejszych. Chodzi tu o sytuacje, które mogą rodzić uzasadnione wątpliwości natury moralno-prawnej, zarówno w relacji do samego faktu niedopełnienia, jak i stosowności udzielenia dyspensy. Zgodnie z brzmieniem n. 2 Ps, będącym rozwinięciem normy kodeksowej, należy do nich zaliczyć stosowanie przez małżonków praktyk onanistycznych, a mówiąc szerzej - egoistyczne zastępowanie naturalnego aktu małżeńskiego poprzez inne, nierzadko dewiacyjne praktyki o charakterze seksualnym, realizowane z inicjatywy jednego lub obydwojga małżonków i obliczone na uzyskanie satysfakcji seksualnej bez „ryzyka” poczęcia dziecka, ponadto w tej kategorii mieści się dokonanie penetracji bez ejakulacji czy też realizacja aktów małżeńskich w sposób całkowicie wymuszony przez współmałżonka, praktyczne odwołanie się do procedury sztucznego zapłodnienia czy też innych technik oferowanych w tym względzie przez nauki medyczne bądź fakt posiadania już przez małżonków potomstwa. Ponadto przedmiotem wątpliwości biskupa może być ryzyko wywołania zgorszenia (np. gdy małżonkowie długi czas mieszkali razem) lub wyrządzenia poważnych szkód materialnych związanych z udzieleniem dyspensy. Należy podkreślić, że przedstawiony wykaz nie ma charakteru taksatywnego, pełni bowiem jedynie rolę orientującą konkretnego biskupa co do zasygnalizowanej problematyki.

${ }^{18}$ Należy zaznaczyć, że zgodnie z KPK kan. 1695 i PS 4 w przypadku przyjęcia sprawy do instrukcji biskup nie może zaniechać podjęcia starań na rzecz pogodzenia się stron. 
Kolejny z omawianej grupy kanonów (kan. 170o) wskazuje, że do przeprowadzenia instrukcji postępowania inkonsumacyjnego biskup diecezjalny może wyznaczyć trybunał swojej diecezji, czy to na sposób stały, czy też w odniesieniu do konkretnego przypadku (ad casum), ma także prawo w umotywowanej sytuacji (np. miejsce zamieszkania świadków i związana z tym ich procesowa osiągalność) powierzyć to zadanie trybunałowi innej diecezji bądź upoważnić określonego prezbitera mającego ku temu odpowiednie kwalifikacje ${ }^{19}$.

W przypadku trwającego procesu o stwierdzenie nieważności małżeństwa i uprzedniego lub późniejszego złożenia prośby o udzielenie dyspensy instrukcja dotycząca tej ostatniej winna być powierzona trybunałowi, który rozpatruje sprawę nieważności ${ }^{20}$. Takie rozporządzenie znajduje swoje uzasadnienie w wymogach ekonomii procesowej. Gdyby zaś prośba o udzielenie dyspensy została złożona do innego biskupa niż ten, któremu podlega trybunał prowadzący proces o stwierdzenie nieważności, powinien on na bazie przesłanych mu przez ów trybunał akt postępowania (wraz z załączoną opinią obrońcy węzła) sporządzić swoje wotum, a następnie zwrócić akta ${ }^{21}$.

Gdy w trakcie prowadzonej instrukcji procesu o stwierdzenie nieważności małżeństwa powstanie uzasadniona wątpliwość co do niedopełnienia związku, wtedy zgodnie z odwołaniem się do brzmienia kan. 1681 trybunał może za zgodą stron zawiesić proces i skierować postępowanie na drogę administracyjną ${ }^{22}$. Następuje wtedy uzupełnienie instrukcji pod kątem ewentualnego niedopełnienia oraz przesłanie akt sprawy

19 Por. KPK kan. $1700 \$ 1$; PS 5 .

${ }^{20}$ Por. KPK kan. $1700 \$ 2$; PS 5 .

${ }^{21}$ Por. KPK kan. $1704 \$ 2$.

${ }^{22}$ Por. KPK kan. 1681, art. $153 \$ \$ 1-2$ DC. Papieska Rada ds. Tekstów Prawnych, doprecyzowując wskazania art. $153 \$ \$ 1-2$ DC, stwierdziła, że chociaż zgoda stron jest konieczna do zawieszenia procesu o stwierdzenie nieważności małżeństwa, nie jest to wymagane do ważności tego aktu. Ponadto milczenie którejkolwiek ze stron można uznać za akt wyrażonej zgody, w przypadku zaś strony pozwanej ogłoszonej nieobecną w procesie należy mimo wszystko zapytać ją o zgodę na jego zawieszenie i podjęcie starań o uzyskanie dyspensy super rato. W nocie wyjaśniającej Papieska Rada zaznacza, że sędzia powinien wezwać stronę pozwaną do pisemnego wyrażenia w określonym terminie swojego stanowiska w tej kwestii, a w przypadku braku odpowiedzi należy to uznać za zgodę na zawieszenie procesu i przejście na drogę administracyjną. Wtedy sędzia winien to potwierdzić dekretem, jak również deklarować stronę pozwaną jako nieobecną także w tym postępowaniu. 
wraz z prośbą petenta, wnioskiem trybunału i wotum biskupa do Roty Rzymskiej.

Następnie prawodawca kodeksowy zaznacza, że w procesie o dyspensę super rato winien zawsze uczestniczyć obrońca węzła ${ }^{23}$. Wymóg ten jest podyktowany samą naturą procesu, który dotyczy dobra publicznego. Choć w omawianej dyspozycji prawodawca nie stanowi tego w sposób wyraźny, można uznać, że jego obecność w postępowaniu jest nakazana pod sankcją nieważności akt ${ }^{24}$. Zadaniem obrońcy jest tutaj przytoczenie wszystkich racjonalnych argumentów przemawiających przeciw uznaniu danego małżeństwa za niedopełnione.

$\mathrm{Z}$ racji administracyjnej natury postępowania w sprawie dyspensy super rato nie ma w nim formalnej dyskusji pomiędzy stronami, stąd też wynika ustawowy zakaz ustanowienia pełnomocnika dla stron bądź jednej z nich. Gdyby jednak w określonej sytuacji zaistniał przypadek wymagający pomocy prawnej, petent lub strona pozwana może ją otrzymać w osobie eksperta ${ }^{25}$. Jak jednak zaznacza doktryna ${ }^{26}$, w rzeczywistości w wielu podejmowanych czynnościach w trakcie postępowania (np. redakcja prośby, pomoc w gromadzeniu środków dowodowych, rozważenie zasadności ponowienia prośby wskutek decyzji negatywnej) wspomniany ekspert pełni nieformalnie funkcję pełnomocnika.

W odniesieniu do sposobu przeprowadzenia instrukcji dowodowej, o czym traktuje kan. 1702, prawodawca kościelny wskazuje na przesłuchanie stron, a także zaleca odwołanie się do innych środków dowodowych obecnych w zwyczajnym procesie spornym i o stwierdzenie nieważności małżeństwa, o ile są one do pogodzenia z charakterem tych

\footnotetext{
Por. Papieska Rada ds. Tekstów Prawnych, Odpowiedź z 2 marca 2005, „Communicationes” 37 (2005), s. 107-112.

${ }^{23}$ Por. KPK kan. $1701 \S 1$.

${ }^{24}$ Por. J. Krukowski, Kanon 17o1, [w:] Komentarz do Kodeksu Prawa Kanonicznego. T. 5. Ks. 7, Procesy, dz. cyt., s. 383. Naszym zdaniem wspomnianą sankcję nieważności należałoby rozumieć tutaj w znaczeniu konieczności uzupełnienia akt sprawy o wymagane uwagi obrońcy przed zakończeniem postępowania w urzędzie w Rocie Rzymskiej.

${ }^{25}$ Por. KPK kan. $1701 \S 2$. Jest to kodeksowe potwierdzenie uregulowania, jakie wprowadziła Instrukcja wydana przez Świętą Kongregację Dyscypliny Sakramentów 7 marca 1973. Por. Instrukcja De quibusdam emendationibus circa normas in processu super matrimonio rato et non consummato servandas, AAs 64 (1972), s. 244-252.

${ }^{26}$ Por. J. Krukowski, Kanon 1701, dz. cyt., s. 384.
} 
procesów ${ }^{27}$. Należy podkreślić, że w interesującym nas przypadku mamy do czynienia $\mathrm{z}$ bardzo intymną i delikatną materią, stąd też złożone pod przysięgą sądowe oświadczenia stron (obok ekspertyz medycznych w przypadku impotencji) są podstawowymi i zasadniczo najbogatszymi treściowo środkami służącymi poznaniu prawdy o fakcie ewentualnego niedopełnienia, jak również jego przyczyn. Jeżeli bowiem strony dzieliły się z kimś swoimi małżeńskimi problemami w tej dziedzinie (np. rodzice, zaufany przyjaciel, psycholog itp.) w tzw. czasie niepodejrzanym (tj. przed złożeniem prośby o dyspensę), wiedza tych osób bywa często fragmentaryczna i może być nacechowana subiektywnie. Z tego względu niebagatelną rolę $\mathrm{w}$ postępowaniu dowodowym odgrywa świadectwo wiarygodności wydane stronom przez właściwego im duszpasterza, jakim jest proboszcz ich miejsca zamieszkania.

Gdy chodzi o klasyfikację dowodów przemawiających za niedopełnieniem małżeństwa, prawodawstwo i doktryna ${ }^{28}$ wyszczególniają następujące:

- argument fizyczny, opierający się na badaniu ginekologicznym kobiety, z którego wynika nienaruszenie fizycznych znamion dziewictwa, a w przypadku mężczyzny chodzi o badanie andrologiczne, które wyklucza jego zdolność do odbycia aktu małżeńskiego;

- moralny, bazujący na świadectwie prawdomówności stron oraz ich sądowym przyznaniu się do niedopełnienia związku, a także uwzględniający inne poszlaki i domniemania wskazujące na taki stan rzeczy, np. zeznania wiarygodnych świadków o mających miejsce bezpośrednio po ślubie przejawach niechęci czy też wrogości stron wobec siebie;

- czasowy (per coarctata tempora) - wskazujący na brak możliwości dopełnienia małżeństwa, wynikający z okoliczności zewnętrznych, np. wyjazd jednej ze stron (np. do pracy, odbycia służby wojskowej itp.) bezpośrednio po ceremonii ślubnej; małżeństwo zawierane przez pełnomocnika, np. w więzieniu itp. W takim wypadku zostaje również obalone domniemanie legalne ustanowione w kan. $1061 \$ 2$.

${ }^{27}$ Mają zatem tutaj zastosowanie przepisy odpowiednio KPK kan. 1526-1586 i DC art. $155-216$.

${ }^{28}$ Por. J. Krukowski, Kanon 1702, [w:] Komentarz do Kodeksu Prawa Kanonicznego. T. 5. Ks. 7, Procesy, dz. cyt., s. 385; G. Incitti, De processu super matrimonio rato et non consummato (Numeri 8-20), [w:] Norme procedurali canoniche commentate, a cura di M. del Pozzo, J. Llobell, J. Miñambres, Roma 2013, s. 225-230. 
- Jak stwierdza dyspozycja kolejnego z analizowanych kanonów (kan. 1703), po zakończonej instrukcji nie jest przewidziana publikacja akt, należy dodać, że nie ma również miejsca formalne zamknięcie postępowania dowodowego ani też dyskusja sprawy. Jednakże w trosce o należyte wyjaśnienie sprawy sędzia powinien udostępnić danej stronie zgromadzony materiał dowodowy (zwłaszcza zarzuty drugiej strony), jeżeli roztropnie uzna, że w przypadku zaniechania tej czynności może wyniknąć dla niej poważna szkoda. Może to również uczynić na żądanie strony, wyznaczając jednocześnie termin, w którym może ona przedstawić pisemnie swoje uwagi ${ }^{29}$.

Po dokonaniu instrukcji sprawy zgodnie z kan. $1704 \$ 1$ instruktor powinien całość akt wraz z załączoną relacją przekazać biskupowi, który przygotowuje swój wniosek pro rei veritate dotyczący zarówno faktu niedopełnienia, jak i słuszności ewentualnego udzielenia dyspensy. Zgodnie $\mathrm{z}$ art. 7 Ps biskup może dostosować swoje wotum do opinii wyrażonej przez instruktora, podpisując ją oraz załączając własne stanowisko co do zaistnienia słusznej przyczyny do udzielenia dyspensy i braku zgorszenia ze strony wiernych. Te same czynności należy podjąć, gdy instrukcję sprawy przeprowadził trybunał innego biskupa niż ten do którego zwrócił się orator ${ }^{30}$.

Zgodnie $\mathrm{z}$ tenorem kan. $1705 \$ 1$ po zakończeniu diecezjalnego etapu postępowania całość akt sprawy wraz z uwagami obrońcy węzła i wotum biskupa należy przesłać do Roty Rzymskiej.

Po otrzymaniu akt urząd rotalny zgodnie $\mathrm{z}$ wewnętrzną procedurą mianuje obrońcę węzła, który przedstawia swoje uwagi, po czym sprawa możne zostać oddalona a limine z powodu braku podstaw za udzieleniem dyspensy, lub, jak dzieje się to zwyczajnie, zostaje powierzona komisji składającej się z trzech lub pięciu komisarzy, którzy po dokonanym studium akt wyrażają swoją opinię co do meritum ${ }^{31}$. Należy zaznaczyć, że decyzja negatywna, będąca wynikiem braku pewności moralnej co do zaistnienia faktu niedopełnienia, zostaje zakomunikowana zainteresowanym

${ }^{29}$ Por. J. Krukowski, Kanon 1703, [w:] Komentarz do Kodeksu Prawa Kanonicznego. T. 5. Ks. 7, Procesy, dz. cyt., s. 386.

${ }^{30}$ Por. KPK kan. $1704 \$ 2$. W przypadku gdy postępowanie prowadził trybunał regionalny lub międzydiecezjalny, wotum pro rei veritate zostaje sporządzone przez biskupa tegoż trybunału. Powinien on jednak odnieść się do biskupa strony proszącej przynajmniej w kwestii stosowności udzielenia dyspensy. Por. Ps 23 b.

${ }^{31}$ Por. G. Incitti, De processu... (Numeri 24-25), dz. cyt., s. 233. 
stronom, które z kolei mogą, także przy pomocy wspomnianego już biegłego w prawie, ocenić możliwość uzyskania innych dowodów, przydatnych w perspektywie ewentualnego ponowienia prośby ${ }^{32}$.

Decyzja powzięta w wyniku zebrania kolegium może być trojakiego rodzaju: obok rozstrzygnięcia pozytywnego może mieć miejsce decyzja zawieszająca albo negatywna opatrzona klauzulą non expedire. Przedstawimy teraz pewne doprecyzowania oraz kontekst każdego z trzech wspomnianych rozstrzygnięć. W przypadku decyzji pozytywnej sprawa zostaje przedstawiona ojcu świętemu w celu ewentualnego udzielenia dyspensy, z kolei zawieszenie decyzji nie ma waloru rozstrzygającego i ma miejsce, gdy zachodzi konieczność uzupełnienia instrukcji sprawy na szczeblu diecezjalnym. Wtedy urząd w Rocie formułuje odpowiednie wskazówki do biskupa prowadzącego instrukcję, zawierając w nich dane dotyczące charakteru nowych dowodów w sprawie oraz polecenie ich uzyskania $^{33}$. Co zrozumiałe, w odniesieniu do tak poszerzonego materiału dowodowego powinien następnie wypowiedzieć się obrońca węzła, zaś na biskupie ciąży obowiązek sporządzenia nowego wotum pro rei veritate et de non timendo scandalo. Po spełnieniu tych czynności akta sprawy zostają z powrotem przesłane do rozpatrzenia w Rocie. Ostatni z możliwych wariantów dotyczy sytuacji, w której co prawda udowodniono niedopełnienie małżeństwa, ale brakuje drugiego $\mathrm{z}$ istotnych elementów przemawiających za udzieleniem dyspensy, jakim jest słuszna przyczyna dokonania tego aktu. Ma to miejsce wtedy, gdy przyczyną niedopełnienia było przewrotne działanie stron w obszarze ich poślubnych seksualnych zachowań, np. egoistyczne rezygnowanie $\mathrm{z}$ aktu seksualnego na rzecz praktyk dewiacyjnych, uporczywe stosowanie środków antykoncepcyjnych itp. W takim wypadku dyspensa papieska nie służyłaby ich dobru duchowemu, lecz jedynie oznaczałaby swoiste usankcjonowanie ich moralnego nieuporządkowania, skutkującego także w perspektywie uznania ich związku za niedopełniony.

Reskrypt zawierający dyspensę zostaje przesłany biskupowi, który zlecił przeprowadzenie instrukcji sprawy, ten zaś winien niezwłocznie poinformować o tym fakcie proboszcza miejsca zawarcia małżeństwa, jak

${ }^{32}$ Por. кPK kan. $1705 \$ 3$, PS 27 . Należy zaznaczyć, że zgodnie z naturą postępowania $\mathrm{w}$ przypadku odpowiedzi negatywnej stronom nie przysługuje apelacja.

33 Por. KPK kan. $1705 \$ 2$, PS 26. 
i przyjęcia chrztu przez strony, oraz nakazać im dokonanie odpowiednich adnotacji (włącznie z zaznaczeniem ewentualnych klauzul zabraniających), zarówno w księdze małżeństw, jak i ochrzczonych ${ }^{34}$.

Podobnie jak w przypadku wykonalnej sentencji deklarującej nieważność małżeństwa, tak i w postępowaniu o udzielenie dyspensy super rato do reskryptu mogą zostać dołączone określone klauzule (wobec obydwojga stron lub jednej z nich), mające na celu zagwarantowanie ważności i godziwości ewentualnego kolejnego małżeństwa. Nie są one jednak przeszkodami w sensie ścisłym (kan. 1075), dlatego też ich formalne pominięcie nie powoduje nieważności związku, lecz jedynie niegodziwość samego aktu (kan. $1077 \$ 2$ ). Ze względu na ich naturę i charakter administracyjny wyróżniamy: zakaz (vetitum) - nakładany stosunkowo rzadko i w przypadkach poważnych, takich jak defekt o charakterze fizycznym lub psychicznym uniemożliwiający realizację aktów małżeńskich (bliskość przeszkody impotencji), oraz klauzulę ad mentem, dotyczącą przyczyn niedopełnienia o mniejszej wadze ${ }^{35}$.

Należy dodać, że gdy z akt sprawy wynika wysokie prawdopodobieństwo nieważności związku (z jakiegokolwiek tytułu), dyspensa jest opatrzona klauzulą ad cautelam super dubio nullitatis matrimonii.

Gdy chodzi o uchylenie wspomnianych klauzul, w przypadku załączonego vetitum biskup zainteresowanej strony powinien odnieść się bezpośrednio do urzędu powołanego dla spraw dyspensy super rato w Rocie i dostosować do otrzymanych tam wytycznych ${ }^{36}$, gdy chodzi zaś o klauzulę ad mentem, biskup winien zapoznać się z zawartymi w reskrypcie instrukcjami i upewnić się dzięki stosownej ekspertyzie medycznej o zdolności zainteresowanej strony do wypełnienia obowiązków małżeńskich bądź przyjąć od niej poważne zobowiązanie ich wypełnienia ${ }^{37}$.

${ }^{34}$ Por. KPK kan. 1706.

${ }_{35}$ Por. J. Krukowski, Kanon 1706, [w:] Komentarz do Kodeksu Prawa Kanonicznego. T. 5.

Ks. 7, Procesy, dz. cyt., s. 389.

${ }^{36}$ Por. PS 24.

${ }^{37}$ Por. Ps 25. Należy zauważyć, że wskazana dyspozycja nie precyzuje osoby biskupa, który powinien zrealizować zalecenia dotyczące uchylenia klauzuli ad mentem, powstaje zatem wątpliwość, czy chodzi o biskupa, który instruował proces, czy też należy tutaj rozumieć biskupa miejsca celebracji nowego związku małżeńskiego. Doktryna nie jest w tej kwestii jednomyślna, ale w oparciu o pogląd, jaki sformułował G. Incitti (De processu... (Numeri 24-25), dz. cyt., s. 234), należy wskazać na biskupa miejsca ponownej celebracji; 


\section{Postępowanie super rato w praktyce Sądu Diecezjalnego w Tarnowie w okresie obowiązywalności aktualnego Kodeksu prawa kanonicznego}

Po ogólnym przedstawieniu kanonicznych aspektów dotyczących faktu niedopełnienia małżeństwa oraz po syntetycznej prezentacji elementów tworzących procedurę uzyskania dyspensy super rato, zostaną teraz przytoczone dane obrazujące obecność tej problematyki w praktyce tarnowskiego Sądu Diecezjalnego.

Gdy chodzi o czasowy przedział analizowanej kwestii, należy przypomnieć, że przedmiotem naszej kwerendy były sprawy wniesione do sądu tarnowskiego (tj. poprzez złożenie prośby o dyspensę w postepowaniu administracyjnym lub wpłynięcie skargi powodowej w przypadku procesu o stwierdzenie nieważności małżeństwa $\mathrm{z}$ uwzględnionym aspektem niedopełnienia) i przyjęte przezeń w okresie od momentu wejścia w życie obecnie obowiązującego Kodeksu prawa kanonicznego (czyli od 27 listopada 1983 roku) do 1 października 2015 roku.

Liczba spraw rozpatrywanych wyłącznie w postępowaniu administracyjnym super rato na przestrzeni analizowanego okresu jest relatywnie niewielka i ogranicza się do 21 przypadków, zaistniałych w okresie od 1984 do 1997 roku. $18 \mathrm{z}$ nich zostało za pośrednictwem nuncjatury apostolskiej w Warszawie skierowanych do Kongregacji Kultu Bożego i Dyscypliny Sakramentów, zaś 3 zakończyły się na etapie diecezjalnym z powodu zrzeczenia się (2 przypadki) i umorzenia (1 sprawa).

Z kolei w 27 wypadkach mających miejsce od 1984 do 2004 roku doszło do zawieszenia procesu i przejścia na drogę administracyjną, zakończoną również poddaniem sprawy pod osąd Biskupa Rzymu. Należy dodać, że w 16 tego typu przypadkach w dekrecie określającym zawiązanie sporu wskazano na impotencję seksualną przynajmniej jednej ze stron (w ośmiu takich sprawach był to jedyny tytuł nieważności, zaś w pozostałych ośmiu towarzyszyły mu inne tytuły, najczęściej była to psychiczna niezdolność do podjęcia istotnych obowiązków małżeńskich [kan. 1095 n. 3] - tak było w siedmiu sprawach - oraz pozorna zgoda [kan. 1101

jest to motywowane pragnieniem zagwarantowania nowemu partnerowi strony odpowiedniej wiedzy o fakcie nałożonej klauzuli. 
$\$ 2]$ - jeden przypadek, kumulatywnie zaś w jednym wypadku zaproponowano błąd co do przymiotu osoby zamierzonego wprost i bezpośrednio [kan. 1097 \2] oraz w jednym wypadku brak używania rozumu [kan. 1095 n.1] i poważny brak rozeznania oceniającego [kan. 1095 n. 2]). W pozostałych 11 przypadkach wskazywano ogólnie na fakt niedopełnienia i - co zrozumiałe - przyjmowano inne niż impotencja seksualna tytuły nieważności (w czterech - wyłącznie zgodę pozorną, w kolejnych czterech - wyłącznie psychiczną niezdolność do podjęcia istotnych obowiązków małżeńskich, a w pozostałych trzech - kumulatywnie zgodę pozorną i kolejno: przymus i bojaźń [kan. 1103], podstęp [kan. 1098] oraz psychiczną niezdolność do podjęcia istotnych obowiązków małżeńskich).

Z pewnością godnym podkreślenia jest fakt, iż we wszystkich zakończonych 45 przypadkach, procedowanych zarówno wyłącznie na drodze administracyjnej (18), jak też po przejściu na nią po uprzednim zawieszeniu postępowania procesowego (27) o stwierdzenie nieważności, Biskup Rzymu udzielił stosownej dyspensy, co w relacji do pracy sędziów trybunału tarnowskiego świadczy zarówno o właściwym rozpoznaniu każdej ze wspomnianych spraw, należytej kwalifikacji dokonanej pod kątem stosowności ubiegania się o papieską dyspensę, jak i rzetelnej i kompletnej realizacji instrukcji dowodowej przez prowadzącego dane postępowanie.

Trudno jednak w sposób jednoznaczny i wyczerpujący ocenić nieobecność w ostatnich latach spraw super rato prowadzonych od początku $\mathrm{w}$ postępowaniu administracyjnym lub po ewentualnym przejściu $\mathrm{z}$ drogi procesu o stwierdzenie nieważności małżeństwa.

Przyczyn takiego stanu rzeczy jest zapewne kilka, a pomocną w ich usystematyzowaniu może być próba spojrzenia na omawiany problem z perspektywy zarówno sędziego prowadzącego daną sprawę, jak i strony procesowej.

Przede wszystkim należy jednak zauważyć, że niedopełnienie małżeństwa może być w pewnych wypadkach (o ile nie w większości) przejawem określonych anomalii natury psychicznej, które z racji swego ciężaru stanowią z kolei wyraźną przesłankę do podania w uzasadnioną wątpliwość konsensualnej zdolności nupturientów, co w konsekwencji prowadzi do procesowego uznania związku małżeńskiego za nieważny. Wzrastająca świadomość tego faktu mogła powodować, że już na etapie konsultacji ze stroną mającą zamiar zaskarżyć swój związek, która wskazała na brak 
poślubnych aktów małżeńskich, sędzia nie ograniczał się jedynie do zgromadzenia informacji niezbędnych do uprawdopodobnienia zasygnalizowanego niedopełnienia, lecz kierował swoją uwagę na szerszy kontekst całej sprawy, proponując w konsekwencji przyjęcie tytułu impotencji lub któregoś z tytułów niezdolności konsensualnej, regulowanej przez kan. 1095 KPK. Takie ujęcie, wskazujące na złożoność omawianej problematyki w jej istotowym wymiarze, może zatem w pewnym stopniu tłumaczyć praktyczne „wypieranie” procedury administracyjnej super rato (nieobecnej w sądowych realiach diecezji tarnowskiej od prawie 18 lat) na rzecz procesowego dowodzenia niemocy płciowej, pozornej zgody lub niezdolności konsensualnej, przede wszystkim z przyczyn natury psychicznej.

Wskazuje na to fakt, że chociażby na przestrzeni ostatnich 10 lat działalności sądu (od początku 2005 roku) we wszystkich procesach o stwierdzenie nieważności małżeństwa ze wskazanym początkowo wymiarem inkonsumacyjnym (w tym z powodu ewentualnej impotencji) ${ }^{38}$ przyjmowano jako tytuł nieważności psychiczną niezdolność do podjęcia istotnych obowiązków małżeńskich (kan. 1095 n. 3), a tylko w jednym przypadku była mowa wyłącznie o zgodzie pozornej (kan. $1101 \$ 2)^{39}$. Co więcej, w każdym z zasygnalizowanych przypadków był wydawany wyrok pozytywny, co z kolei potwierdza intuicję sędziów i stron w odniesieniu do sensowności zapoczątkowania i kontynuacji procesu.

W relacji zaś do prawdopodobnej „niechęci” tarnowskich sędziów do modyfikowania sposobu procedowania $\mathrm{z}$ sądowego na administracyjne nie można wykluczyć tego, iż w niektórych przypadkach fakt ewentualnego niedopełnienia mógł okazywać się w trakcie instrukcji o wiele trudniejszy do udowodnienia, niż pierwotnie zakładano, co z kolei było elementem wzmacniającym decyzję o pozostaniu na drodze procesu o stwierdzenie nieważności małżeństwa w oparciu o tytuły dotyczące wad zgody małżeńskiej.

$\mathrm{W}$ odniesieniu do stron biorących udział w procesie należałoby zwyczajnie wskazać na ekonomię procesową, która w dużej mierze determinuje postawy i zachowania wszystkich uczestników procesu. Można przyjąć, że strony w nadziei uzyskania korzystnego dla siebie rozstrzygnięcia

${ }^{38}$ Liczba ta obejmuje 26 przypadków, w tym jeden umorzony.

${ }^{39} \mathrm{~W}$ dwóch przypadkach ten tytuł został przyjęty kumulatywnie. 
na drodze procesowej nie były raczej zainteresowane staraniem się o udzielenie dyspensy, czy to od początku, czy też w trakcie procesu, tym bardziej że mogło to rodzić obawy związane z generowaniem dodatkowych kosztów i relatywnie długim oczekiwaniem na zakończenie kongregacyjnego etapu procedury. Nie bez znaczenia pozostaje tutaj fakt ogólnie niskiej (często niezawinionej) świadomości wiernych co do specyfiki kanonicznego procesu małżeńskiego, a tym bardziej procedury dyspensacyjnej super rato. Można przyjąć, że wnosząc skargę powodową, są oni nastawieni przede wszystkim na kanoniczne uregulowanie swojej obecnej sytuacji, jaką jest nierzadko trwanie już w nowej relacji ad instar matrimonii, czy to usankcjonowanej cywilnie, czy też realizowanej na sposób konkubinatu, zaś sposób, w jaki kanonicznie „uwolnią się” od poprzedniego związku, pozostaje dla nich kwestią drugorzędną, a nawet całkowicie obojętną. W tym świetle istotna różnica pomiędzy stwierdzeniem nieważności małżeństwa czy też jego rozwiązaniem wskutek dyspensy papieskiej nie ma dla nich większego znaczenia, tym bardziej że i nierzadko otoczenie, w jakim żyją, przejawia w tej kwestii całkowitą ignorancję, określając efekt finalny wspomnianych procedur (zwłaszcza wyrok pozytywny) mianem rozwodu kościelnego ${ }^{40}$. W tym kontekście nabiera szczególnego znaczenia szeroko rozumiane poradnictwo kanoniczne, o czym zdecydowanie wspomina papież Franciszek w opublikowanym 8 września 2015 roku liście apostolskim wydanym w formie motu proprio Mitis Iudex Dominus Iesus, konkretnie zaś w załączonych doń wytycznych ${ }^{41}$.

${ }^{40}$ Identyczny sposób myślenia stron można zauważyć w przypadku śmierci jednej $\mathrm{z}$ nich $\mathrm{w}$ trakcie toczącego się procesu. Wtedy najczęściej druga strona dokonuje zrzeczenia się instancji, rezygnując $\mathrm{w}$ ten sposób $\mathrm{z}$ dążenia do poznania obiektywnej prawdy o swoim małżeństwie. O ile w przypadku strony pozwanej brak woli kontynuowania procesu i ponoszenia związanych z tym kosztów wydaje się w pewnym stopniu zrozumiały, choć oczywiście nie w pełni usprawiedliwiony, o tyle renuntiatio strony powodowej dowodzi, że pierwszorzędną intencją zaskarżenia małżeństwa i zapoczątkowania procesu było pragnienie kanonicznego „uwolnienia się” od współmałżonka, co wskutek jego śmierci stało się faktem.

${ }^{41}$ Por. Franciszek, list apostolski Mitis Iudex Dominus Iesus. Ratio procedendi in causis ad matrimonii nullitatem declarandam, art. 2, https://w2.vatican.va/content/francesco/la/ motu_proprio /documents/papa-francesco-motu-proprio_20150815_mitis-iudex-dominus-iesus.html (15.10.2015). 
Wskutek takiego stanu rzeczy można przyjąć ze sporym prawdopodobieństwem, że zarysowana w ostatnim dziesięcioleciu tendencja będzie się utrzymywała, tym bardziej iż w trwających jeszcze dziewięciu procesach uwzględniających aspekt niedopełnienia jako tytuły nieważności przyjęto niezdolność do podjęcia istotnych obowiązków małżeńskich z przyczyn natury psychicznej (7 przypadków) ${ }^{42}$ oraz impotencję (2 przypadki), nie wskazano również przejścia na drogę administracyjną. Trudno również przewidzieć, czy przeniesienie kompetencji w sprawach o udzielenie dyspensy super rato do Roty Rzymskiej spowoduje w niedalekiej przyszłości powrót do zastosowania tej procedury na szczeblu diecezjalnym; naszym zdaniem raczej nie, gdyż, jak zaznaczyliśmy wyżej, krok ten nie niesie za sobą jakichkolwiek uproszczeń formalnych, co w zestawieniu z wymogiem ekonomii procesowej nie pozostaje bez znaczenia.

Co zrozumiałe, globalna ocena częstotliwości stosowania procedury dyspensacyjnej super rato $\mathrm{w}$ realiach praktyki sądu tarnowskiego nie ma waloru negatywnego, wskazuje jedynie na pewne przesunięcie akcentów w służbie na rzecz sprawiedliwości wobec wiernych, którzy, nierzadko znajdując się w bardzo skomplikowanej sytuacji życiowej, pragną kanonicznie uregulować swój status, zawrzeć sakramentalny związek małżeński i w pełni uczestniczyć w Eucharystii, a także troszczyć się o religijne wychowanie dzieci. $Z$ duszpasterskiego punktu widzenia istotny jest bowiem nie tyle sam wybór określonej procedury w sprawach małżeńskich, ile jej adekwatność do określonej sytuacji oraz odpowiadające kanonicznym wymogom jej sprawne zastosowanie.

${ }^{42} \mathrm{~W}$ jednym $\mathrm{z}$ nich został dodany tytuł poważnego braku rozeznania oceniającego co do praw i obowiązków małżeńskich. 